\title{
Brown Zonate Leaf Blight, a New Disease of Tea Plant Caused by Ceuthospora lauri in Japan
}

\author{
Yasuo ANDo*, Masaomi OnIKI*, Toshiyuki NonAKA** \\ and Nobuyoshi NARISAWA*
}

\begin{abstract}
An unknown leaf blight of the tea plant was found in Kagoshima and Shizuoka Prefectures, Japan, in the spring of 1984 and 1985, respectively. The lesions were reddish to greenish brown in color, almost round in shape and zonate. The causal fungus was identified as Ceuthospora lauri (Greville) Greville on the basis of the morphological characteristics and the pathogenicity onto the tea plant. Brown zonate leaf blight was proposed as the common name of the disease. The present fungus was isolated for the first time in Japan.
\end{abstract}

(Received July 28, 1988)

Key words: Ceuthospora lauri, tea plant, brown zonate leaf blight.

\section{INTRODUCTION}

In the spring of 1984 and 1985, a previously unrecorded leaf blight of the tea plant, Camellia sinensis (L.) O. Kuntze, was detected in Kagoshima and Shizuoka Prefectures, Japan, respectively. This report describes the new disease of the tea plant, its causal fungus, and the results of etiological studies. Brief reports of this work have been published elsewhere ${ }^{1,2}$.

\section{MATERIALS AND METHODS}

Isolation. Naturally diseased tea leaves were collected in the fields in Kanaya, Shizuoka Prefecture, in March and April, 1985. Spore horns from pycnidia on the lesions incubated in a humid box at $15 \mathrm{C}$ for $3 \sim 5$ days (Plate I-4) were placed on potato-sucrose agar (PSA) in 9-cm petri dishes with a sterile needle. After culture at $15 \mathrm{C}$ for 3 days, agar blocks with hyphal tips from the periphery of the colony were transferred into PSA slants. The following five isolates were used throughout this study: CL8501, CL8503, CL8505, CL8507 and CL8512.

Morphological observation. The morphology of the pathogen on naturally diseased leaves and on fallen leaves with stromata which were continuously observed in the fields was examined under a light microscope.

Culture experiments. Colonies of the respective isolates on PSA were observed. Temperature responses of the fungus were studied by determining the mycelial growth rates on PSA incubated at various temperatures ranging from 4 to $35 \mathrm{C}$.

Inoculation experiments. The mycelial agar discs, $4 \mathrm{~mm}$ in diameter, used as inocula were cut from the periphery of the 5-day-old PSA colony cultured at $18 \mathrm{C}$ with a cork borer. Inoculation was conducted by placing each inoculum on a leaf of the tea (cv. Yabukita) planted in a clay pot and on a detached intact leaf or a wounded leaf with a 3-mm cross-edge.

* National Research Institute of Vegetables, Ornamental Plants and Tea (NIVOT), Kanaya, Shizuoka 428, Japan 農林水産省野菜・茶業試験場

** Kagoshima Tea Experiment Station, Chiran, Kagoshima 897-03, Japan＼cjkstart鹿児島県茶業試験場 
These inoculated, potted plants were kept in a growth chamber (day $12 \mathrm{hr}$, night $12 \mathrm{hr}$ ) at 15 $\mathrm{C}$, and the detached leaves were incubated in a humid box at $15 \mathrm{C}$ and $4 \mathrm{C}$ in the dark for 5 10 days.

\section{RESULTS}

\section{Lesions and characteristics of the disease}

The new leaf blight was observed from autumn to spring. The disease occurred more frequently in young tea fields than in mature ones. The diseased leaves were mostly found near the ground, and occasionally on the upper part of the plants. The lesions mostly developed from the periphery of the leaves. They were reddish to greenish brown in color, and almost round in shape and zonate (Plate I-1). The boundary between the lesion and the healthy area was clear, and sometimes there was a distinct dark violet margin around the lesion. Black pycnidia were produced in the lesion on both surfaces (Plate I-2, 4).

The diseased leaves fell easily. Lesions on the fallen leaves developed rapidly, in which many black, sclerotium-like stromata were produced, while no new pycnidia were formed (Plate I-5). On a few leaves attached to the tea plant, stromata were also produced in May and June.

In October, many locules were formed within the stromata in which numerous conidia were produced (Plate I-10), and the ostioles opened on the surface of the stroma (Plate I-9).

\section{Morphology of the causal fungus}

The pycnidia formed in the lesion were often zonate (Plate I-4), immersed, separate, occasionally gregarious, globoid, rarely flattened, unilocular, thick-walled, composed of brown to dark brown pseudoparenchymatous cells, 150 250 (400) $\times(130) 180 \sim 450(1,000) \mu \mathrm{m}$ in size, and opened at the apex by brownish black single ostioles (Plate I-2, 3). Conidiophores were up to $20 \times 3.5 \mu \mathrm{m}$, hyaline, branched irregularly, septate, smooth, and derived from the inner cells of the pycnidia. Conidiogenous cells were hyaline, cylindrical, formed terminally and laterally on septate, branched conidiophores, and phialidic with minute collarettes (Plate II-7). Conidia were hyaline, cylindrical, aseptate, smooth, eguttulate, $11 \sim 15 \times 2.8 \sim 3.2 \mu \mathrm{m}$ in size, and with an apical, fan-shaped, gelatinous appendage (Plate II-5, 6).

The stromata were sclerotium-like, immersed, black, circular to oval, up to $2 \mathrm{~mm}$, mostly up to $1 \mathrm{~mm}$ in diameter (Plate I-5, 6), and occupied the upper and lower epidermises and the parenchyma inbetween (Plate I-7). The stromata were separated from the surrounding leaf tissue by dark brown walls, and filled with pale brown swollen hyphae (Plate I-8). Single or aggregated locules, $100 \sim 250 \mu \mathrm{m}$ in diameter, with a separate ostiole or communal ones were formed within the stromata and hyaline to pale brown (Plate I-10). The morphology and sizes of the conidia, conidiophores and conidiogeneous cells formed in the locules of the stromata were similar to those of the corresponding organs in the pycnidia.

\section{Culture experiments}

Mycelial colony of the fungus isolated on PSA was first grayish white, becoming gray later, and zonate (Plate II-1). The fungus grew at $4 \mathrm{C}$, but failed to grow at higher temperatures than $30 \mathrm{C}$ (Fig. 1). Optimum temperature for mycelial growth was $20 \mathrm{C}$.

Many stromata were easily produced in the medium without any treatment (Plate II-2).

Pycnidia without stromata in the medium were also formed inside and around incisions by cutting the mycelia with a cork borer at the periphery of the colony at 15 C (Plate II-3, 4).

\section{Inoculation experiments}

On the leaves of the potted tea plants, greenish brown lesions were formed around the inocula on the wound within $2 \sim 3$ days after inoculation and expanded up to $2 \mathrm{~cm}$ in diameter for $7 \sim 10$ days (Plate I-11), but no leaf blight occurred on the intact leaves. At first, pycnidia were produced on the lesions. When the temperatures increased to $20 \mathrm{C}$, stromata were produced on the lesions of the leaves attached to the tea plant. Stromata were also easily formed on the detached, diseased leaves. Pycnidia, stromata and conidia which were produced by 


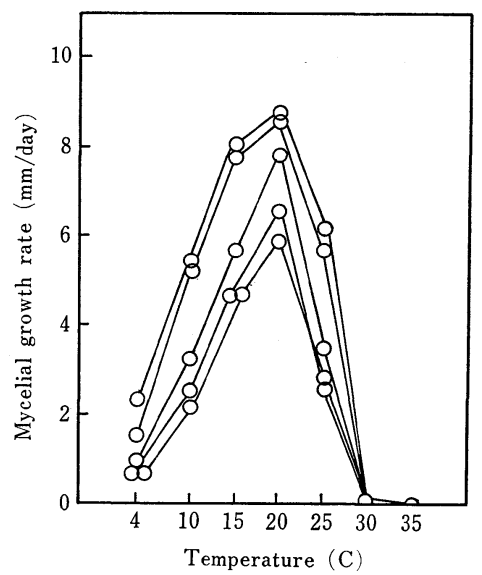

Fig. 1. Mycelial growth rates of five test isolates of Ceuthospora lauri from tea plant on PSA at different temperatures.

artificial inoculation were similar to those in the natural infection.

On the detached leaves, greenish brown lesions with stromata were formed only on the wounded leaves several days after inoculation at $15 \mathrm{C}$, but no pycnidia were produced on the lesions. The lesions with stromata also formed at $4 \mathrm{C}$ although it took a longer time than at $15 \mathrm{C}$.

\section{DISCUSSION}

The causal fungus of the new leaf blight of the tea plant was identified as Ceuthospora lauri (Greville) Greville (1827) based on its morphological characteristics ${ }^{3,4}$ ) and the pathogenicity.

Since the temperature plays an important role in the life cycle of $C$. lauri, time of the occurrence of the disease caused by the fungus is depended on the temperature. In the field, stromata are easily formed on fallen diseased leaves in autumn to spring. C. lauri may easily infect fallen and dying leaves. In this case, the fungus produces stromata only. Because $C$. lauri is unable to grow at higher temperatures than $30 \mathrm{C}$, it may aestivate in the stromata, and sporulate as the temperature decreases in autumn. Principally, the source of primary infection can be found in fallen diseased leaves on litter under the tea plant because few diseased leaves with stromata remain attached to the tea plant. The conidia pushed out from the ostioles on stromata are dispersed to neighboring leaves probably and mainly by rain and may infect through wounds.

It is considered that pycnidia produced by $C$. lauri in the natural infection and in the medium under certain conditions are conidiomata independently formed without stromata. In the tea field, pycnidia without stromata are produced only in the lesions on the vigorous leaves attached to the tea plant, and conidia produced in the organ may serve as the source of secondary infection. Therefore, the disease caused by $C$. lauri occurs from autumn to spring in Japan.

The common name of brown zonate leaf blight ("kassyoku rinmonbyo" in Japanese) is proposed for this new disease of the tea plant.

This is the first report on C. lauri in Japan.

\section{Literature cited}

1. Ando, Y., Nonaka, T., Oniki, M. and Narisawa, N. (1986). Ann. Phytopath. Soc. Japan 52: 100 (Abstr. in Japanese).

2. Ando, Y., Oniki, M., Nonaka, T. and Narisawa, N. (1986). Ibid. 52: 535 (Abstr. in Japanese). 
3. Sutton, B.C. (1972). Taxon 21: 319-326.

4. Sutton, B.C. (1980). The Coelomycetes. Commonwealth Mycological Institute, Kew. pp. 471-473.

\section{和 文 摘 要}

安藤康雄・鬼木正臣・野中寿之・成澤信吉 : Ceuthospora lauri によるチャ褐色輪紋病（新称）

鹿児島県扰よび静岡県に执いて，それぞれ 1984 年抢よび 1985 年の春にチャに未報告の葉枯性病害が発 生した。本病は葉に発生し, 病斑は赤褐色あるいは緑褐色, 円形, 輪紋状を呈していた。形態的特徴拉よび チャに対する病原性から病原菌をCeuthospora lauri (Greville) Greville と同定し, 病名として褐色輪紋病を 提唱した。また，本菌は本邦初記載である。

\section{Explanation of plates}

Plate I. Diseased tea leaves (cv. Yabukita) naturally (1 10) and artificially (11) infected with Ceuthospora lauri.

1. Lesion.

2. Pycnidia.

3. Longitudinal section of a pycnidium.

4. Pycnidia with spore horns.

5. Detached leaf with pycnidia and stromata 7 days after incubation in a humid box at $24 \mathrm{C}$.

6. Stromata on a fallen leaf.

7, 8. Longitudinal sections of stromata in Plate I-6.

9. Stromata with ostioles.

10. Longitudinal section of a stroma in Plate I-9.

11. Lesion of a tea leaf artificially inoculated with C. lauri (CL8505) and incubated at $15 \mathrm{C}$ for 10 days.

(scale: $2=500 \mu \mathrm{m} ; 3=50 \mu \mathrm{m} ; 7,9=500 \mu \mathrm{m} ; 8=10 \mu \mathrm{m} ; 10=100 \mu \mathrm{m}$ )

Plate II. Culture of C. lauri (CL8505) on PSA (1 4) and the organs of the fungus formed in nature $(5 \sim 8)$.

1. Colony at $20 \mathrm{C}$ for 7 days.

2. Colony at $20 \mathrm{C}$ for 20 days with stromata.

3, 4. Pycnidia (p) formed by cutting the mycelia with a cork borer in the medium at $15 \mathrm{C}$. s: stromata.

5, 6. Conidia. (6: phase contrast).

7. Conidiogenous cells and conidia.

8. Germination of conidia.

(scale: $3=5 \mathrm{~mm} ; 4=500 \mu \mathrm{m} ; 5 \sim 7=10 \mu \mathrm{m} ; 8=20 \mu \mathrm{m}$ ) 


\section{Plate I}
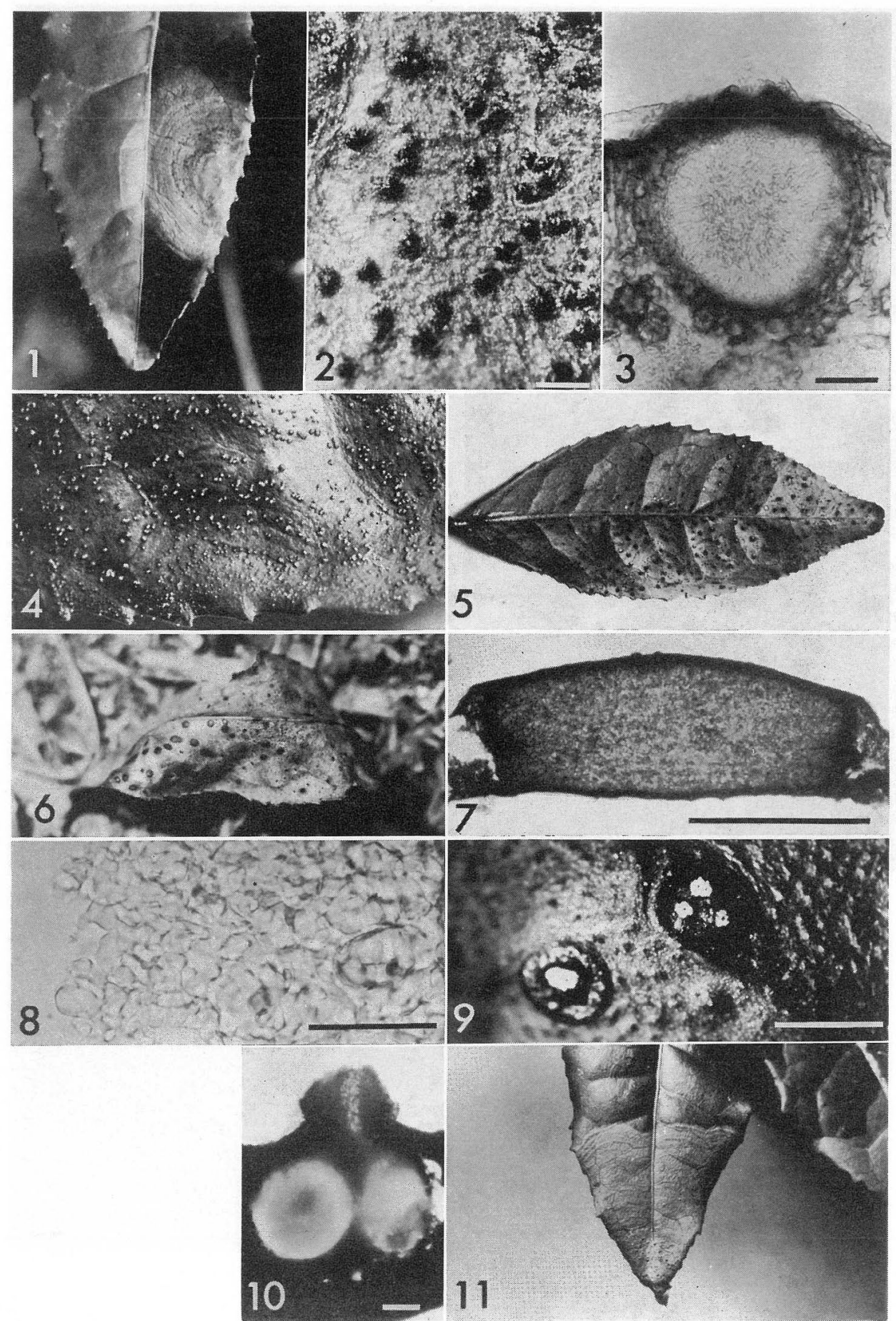
Plate II

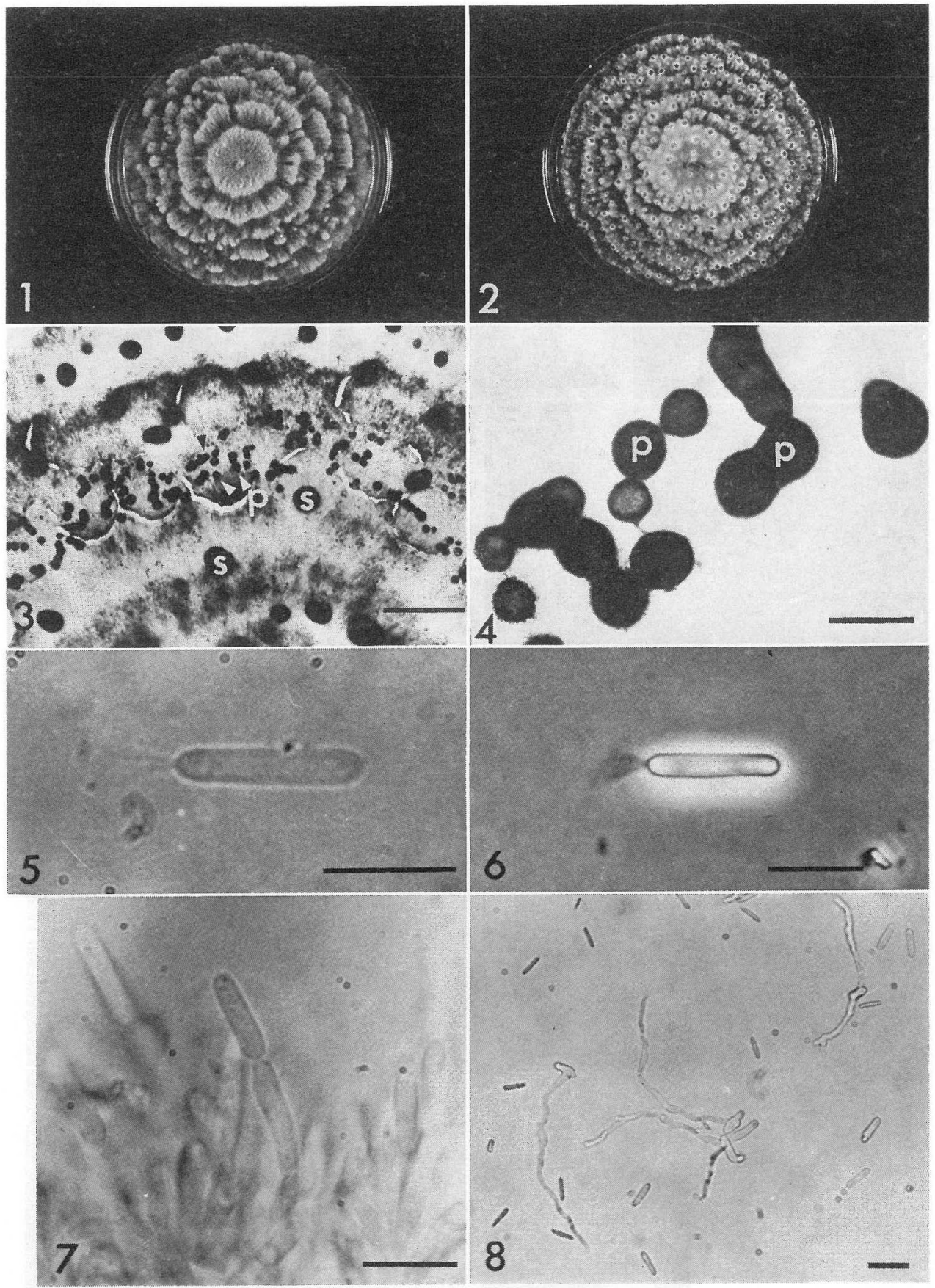

